\title{
インドネシアKahayan川のエルニーニョ現象に 着目した水位予測に関する研究 \\ STUDY ON WATER LEVEL FORECASTING FOR THE KAHAYAN RIVER IN INDONESIA THAT TAKES EL NIÑO EVENT INTO CONSIDERATION
}

\author{
工藤俊 ${ }^{1}$ ・ 中津川誠 ${ }^{2}$ \\ Shun KUDO and Makoto NAKATSUGAWA \\ 1学生会員 室蘭工業大学大学院 工学研究科（干050-8585 室蘭市水元町27-1） \\ 2正会員 博士 (工学) 室蘭工業大学大学院 工学研究科（
}

\begin{abstract}
This study aims to develop a method for forecasting the water level of the Kahayan River in Indonesia. In recent years, peatland in that basin has been drying as a result of agricultural development, and such drying has led to more frequent large-scale wildfires there.

By incorporating the sea surface temperature, which is affected by the El Niño event, into a NearestNeighbor Method (NNM), the water level forecasting accuracy was improved even in case that the lead time of prediction was extended. In addition, highly accurate water level forecasts were obtained by using predicted rainfall calculated by NNM and a tank model that can reproduce the hydrological cycle in the basin. Accordingly, a method for forecasting the water level even when data are missing was proposed. The results promise to be useful for basin management to prevent peatland wildfires.
\end{abstract}

Key Words : Kahayan River, peat fires, water level forecasting, Nearest-Neighbor Method, El Niño event, Sea Surface Temperature

\section{1. はじめに}

インドネシアの熱帯泥炭には多量の炭素が蓄積されて いるが，近年の農地開発による地下水位低下などが原因 とみられる泥炭地の乾燥化が起き，大規模な火災を引き 起こしている1).それにより中部カリマンタンだけでも 毎年, 日本の年間排出量に相当するほどの膨大な量の二 酸化炭素が放出されており ${ }^{2}$ 国際的な問題となっている.

このため, 泥炭火災を防ぐために地下水位を正常な状 態にコントロールし泥炭地の乾燥を抑制することが求め られており，そのためには現地の水文環境を理解し，さ らにその変動を把握した上で対策を講じる必要がある. これまで，中部カリマンタンに位置するKahayan川と， 隣接するSebangau川を接続するKalampangan地区を対象 に蒸発散量と流出量の推定を行った三宅ら ${ }^{3)}$ の研究, Sebangau川上流域において有効雨量や蒸発散量を推定し て水収支の検討を行ったKayama ら) $^{4}$ の研究, Kahayan川 流域での近年の水収支を検証した上で上流域において流 出再現計算を試みた辻ら5の研究など，現地の水文環境 に着目した研究がある.
一方，筆者らはこれまで行われてこなかったKahayan 川の水位変動要因の分析を試みた結果, Kahayan川の水 位低下はEl Niño event発生時に顕著になることを検証し， さらに低水時の水位をNearest-Neighbor Method（以下, NNM）を用いて予測することを試みてきた6).

Kahayan川流域は地理情報，水文情報が日本のように 充実していないため，解析を行うにあたってはデータが そしいことを勘案しなければならないという背景がある. そこで，流域水収支の定量化と上流域からの水供給量の 連続データを把握し流域の基礎情報を得ること, また, データが乏しい中での水位予測手法の確立は泥炭火災の 抑制に向けた流域管理を実施する上では非常に重要であ ると考える. そこで本研究では，以下の手順により水位 予測を行うとともに流域の基礎情報の推定を試みた.

1) データがそしい中での水位予測手法としてNNMを 採用し，さらにEl Niño eventそのものを水位予測に 反映させるためにNNMの構成因子にSea Surface

Temperature（以下，SST）を加え精度向上を試みる.

2) 流域水収支を検証した上で流出モデルを確立する とともに，SSTを用いたNNMで雨量予測を試み， 流出モデルと予測雨量によって実測水位が久測で 


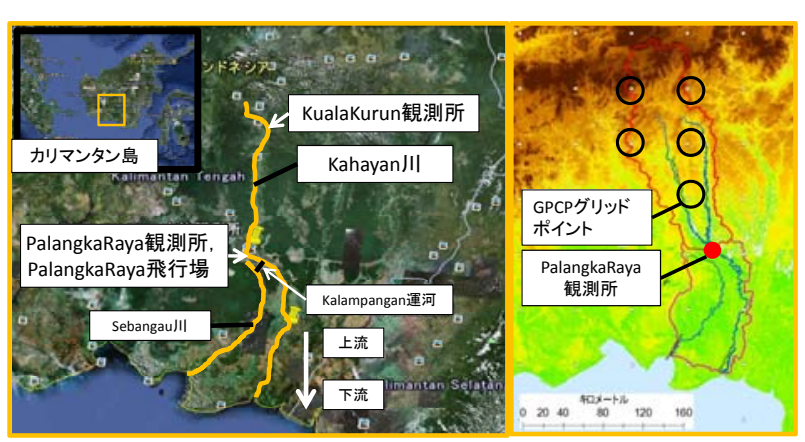

図-1 Kahayan川の位置, 流域内観測点, 流域界, GPCPグリッドポイント

あっても水位予測が可能となる方法を提案する.

\section{Kahayan 川の概要}

Kahayan川はインドネシア・中部カリマンタンに位置 し，流域面積については中央カリマンタン州政府(Dinas PU Propinsi Kalimantan Tengah)によると，19,917km² とさ れている。本研究では周囲に豊かな泥炭地が広がる PalangkaRaya観測所（図-1参照）を対象として水位予測 を行った. なお, PalangkaRaya観測所流域の流域面積に 関しては，全球標高データであるASTER-GDEMとGIS を用いて12,570 $\mathrm{km}^{2}$ と推定した. PalangkaRaya観測所周辺 は，Kahayan川と隣接する Sebangau川を接続する Kalampangan運河（図-1参照）が存在し泥炭地の乾燥化 に大きく関係しており，泥炭火災の抑制に向けた対策を 考える上で重要な地点となる.

\section{NNM による水位予測}

本章では，筆者らによる既往研究6)における水位予測 の精度を向上させ，流域管理に向けてより実用的なもの とすることを目指す．具体的には当該地域の降雨量の多 寡を左右すると考えられるEl Niño eventを水位予測に反 映させるために，日付変更線付近から南米ペルー沖沿岸 にかけてのSSTに着目した．初めにSSTと水位の相関関 係を分析した上で，SSTをNNMに組み込んだ水位予測を 試みて精度が向上するかを検証した。

なお，本研究では低水時の予測に主眼を置いており， 低水時を事前に予測することで河川・水路の堰上げを行 い泥炭地の乾燥を事前に抑制することに役立てたいと考 えているが，現地での実用性を考えると日単位での堰の オペレーションは難しいことを考慮し，月単位での予測 を試みた。よって，NNMを実施するにあたり使用する データは全て月データである.ここで，水位データの月 平均值を算出する際，実測水位には欠測があるため1ヶ 月間の日数の8割以上の日数で観測された月のみの平均 を月平均水位として算出し, 観測日数が8割に満たない
月は久測とした。雨量データについてはPalangkaRaya観 測所流域内において長期に渡って雨量観測が行われてい るPalangkaRaya観測所とKualaKurun観測所（図-1参照） の算術平均雨量を用い，1ケ月間の日数の8割以上の日数 で観測された月の日平均雨量を算出し，それに1ケ月間 の日数を乗じることにより月雨量を算出した.

\section{（1） NNMの概要}

NNMはパターンマッチング手法の一種であり，現在 の水位パターンと類似した水位パターンを過去の水位 データから抽出し, 抽出された過去の水位パターンの将 来水位を予測水位とする手法である. なお，イメージ図 を加えたより具体的な説明については，筆者らによる既 往報告6に記されているので参照されたい.

NNMでは類似した過去の水位パターンの抽出には, 次式のユークリッド距離が小さくなるものを抽出する. ユークリッド距離=

$\sqrt{\left\{H_{X}(n)-H_{X}(m)\right\}^{2}+\left\{H_{X}(n-1)-H_{X}(m-1)\right\}^{2}+\cdots}$

ここで, $H_{X}(n)$ はX地点の現在水位, $H_{X}(m)$ はX地点の過 去水位， $n-1, m-1$ はそれぞれ1時点前データである. こ の際，何時点前のデータまで考えるか（連続する水位の 個数, 以下M）と，何個の過去事例を抽出するか（事例 の抽出数，以下K）を設定する必要がある.また，他の 水文データの現在と過去のパターンの比較も合わせて利 用でき，これを構成因子という。例えば水位と雨量を構 成因子とするときは，ユークリッド距離を計算する際に 現在の水位データと過去の水位データの差に加えて, 現 在の雨量データと過去の雨量データの差も式に組み込ん でいく.

NNMを用いた水文資料の予測については，Karlsson and Yakowits ${ }^{7}$ が実時間洪水予測に初めて応用した。また， Galeati $^{8)}$ ，藤原ら ${ }^{9)}$ は融雪のある河川の日流量予測に適用 し，感潮河川の水位予測へ適用した満倉ら ${ }^{10)}$, Kahayan 川の日単位水位予測を試みた三野ら ${ }^{11)}$ の研究事例がある が，低水位予測に主眼を置いた研究は稀であるといえる.

なお, PalangkaRaya水位と雨量の数值の標準偏差には 約100倍の差が存在する.このためユークリッド距離の 算出時に，水位によるものと雨量によるものが等価でな くなるといった問題が生じる. よって, 雨量データを 100で除し，水位データと雨量データの標準偏差をおお よそ揃え，水位と雨量のユークリッド距離に寄与する重 みを等価にするという処理を行った。

\section{（2）SSTの概要と水位との相関関係の検証}

使用したSSTデータは気象庁 ${ }^{12)}$ がEl Niño event発生の判 断基準としているエルニーニョ監視海域「NINO.3」

（5N-5S，150W-90W）の月毎の海面水温值であり，El Niño event発生時はSSTが平年に比べて高くなる.

SSTをNNMの構成因子に加えるに先立ち, SST と水位 


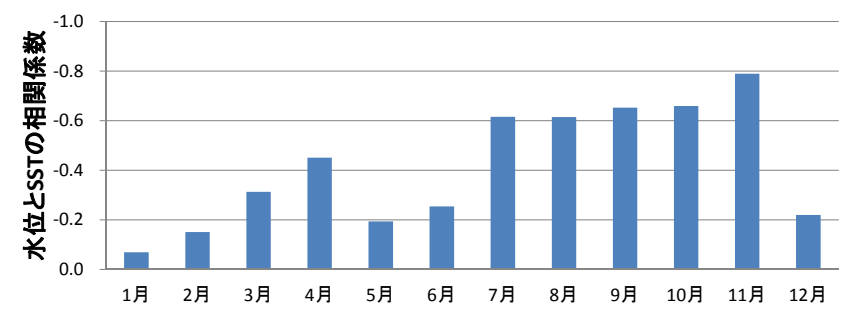

図-2 SSTと水位の相関分析

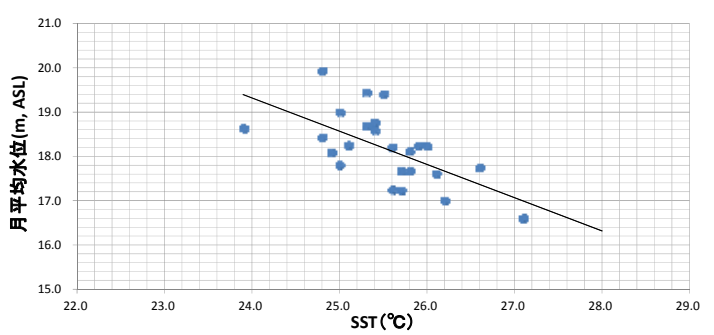

図-3 7月のSST〜水位関係

\begin{tabular}{|c|c|c|c|c|c|c|c|}
\hline 予測パターン & 予測対象 & リードタイム & 構成因子 & 連続データ数 (M) & 抽出水位数 (K) & RMSE & Dry-RMSE \\
\hline (1) & 水位 & 1ヶ月 & \multirow{4}{*}{ PalangkaRaya水位, 雨量 } & \multirow{4}{*}{$M W p=3, M R=2$} & \multirow[t]{8}{*}{ 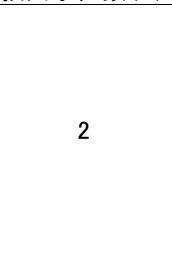 } & $0.876(\mathrm{~m})$ & $0.839(\mathrm{~m})$ \\
\hline (2) & 水位 & 2ヶ月 & & & & $1.136(\mathrm{~m})$ & $1.464(\mathrm{~m})$ \\
\hline (3) & 水位 & 3ヶ月 & & & & $1.368(\mathrm{~m})$ & $1.708(\mathrm{~m})$ \\
\hline (4) & 水位 & 4ヶ月 & & & & $1.533(\mathrm{~m})$ & $1.818(\mathrm{~m})$ \\
\hline (5) & 水位 & 1ヶ月 & \multirow{4}{*}{ PalangkaRaya水位, 雨量, SST } & \multirow{4}{*}{$M W p=3, M R=2, M S=2$} & & $0.760(\mathrm{~m})$ & $0.575(\mathrm{~m})$ \\
\hline (6) & 水位 & 2ヶ月 & & & & $0.918(\mathrm{~m})$ & $0.884(\mathrm{~m})$ \\
\hline (7) & 水位 & 3ヶ月 & & & & $0.820(\mathrm{~m})$ & $0.841(\mathrm{~m})$ \\
\hline (8) & 水位 & 4ヶ月 & & & & $0.884(\mathrm{~m})$ & $0.803(\mathrm{~m})$ \\
\hline (9) & 雨量 & 1ヶ月 & 雨量 & $\mathrm{MR}=3$ & \multirow[b]{2}{*}{3} & $130(\mathrm{~mm} / \mathrm{mon})$ & $172(\mathrm{~mm} / \mathrm{mon})$ \\
\hline (10) & 雨量 & 1ヶ月 & 雨量, SST & $M R=3, M S=4$ & & $88(\mathrm{~mm} / \mathrm{mon})$ & $68(\mathrm{~mm} / \mathrm{mon})$ \\
\hline (11) & 水位 & 1ヶ月 & \multicolumn{3}{|c|}{ 予測パターン(10)の予測雨量をタンクモデルに入カ } & $1.033(\mathrm{~m})$ & $0.692(\mathrm{~m})$ \\
\hline
\end{tabular}

- 実測 ・ャ予測パターン1 —予測パターン(5)

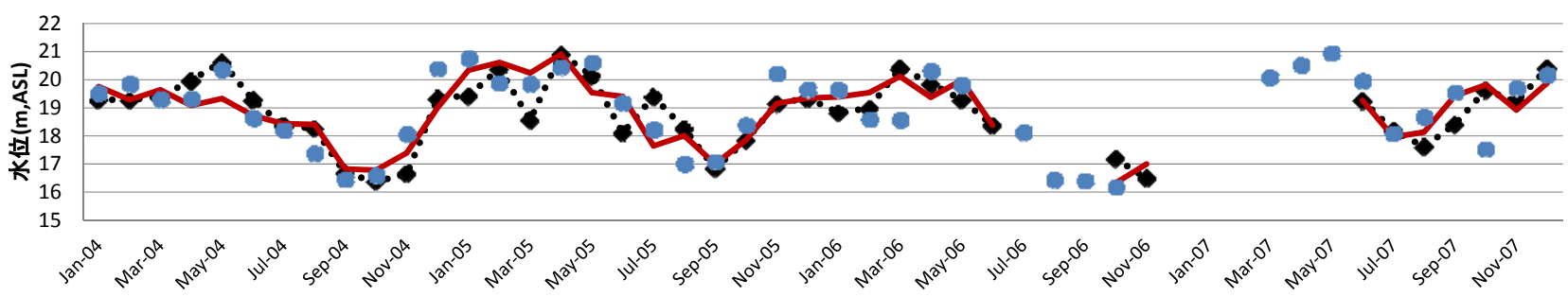

図-4 実測水位と予測パターン(1)と予測パターン5の比較（リードタイム : 1ヶ月）

の相関関係の検証を行う。SSTと水位の1980年〜2011年 の月データを使用して月毎に相関係数を求めた結果を図 -2に示す．図-2に着目すると，カリマンタンの乾季であ る7月〜9月に関しては十分な相関関係があることがわか る.また，7月のSST〜水位関係をプロットし回帰直線 を引いたものを図-3に示寸が，SSTと水位の間に負の相 関があることが読み取れる.

\section{（3）SSTを構成因子に加えた水位予測}

前節においてSSTと水位の相関関係が検証されたが, 本節ではSSTをNNMの構成因子に加えた水位予測を試み る.ささら，本節ではリードタイムを伸ばした水位予測 も試み，各予測条件における予測結果を表-1に示した. なお，誤差評価にはRMSEを用い，さらに乾季に着目し た誤差として，7月～9月のみを抽出したRMSE（以下， Dry-RMSE）についても合わせて用いる．また，NNMに よる予測計算を行う上ではK，Mの值を選定しなければ ならないが，K，PalangkaRaya水位のM（以下，MWp）, 雨量のM（以下，MR）の值は筆者らの既往研究6)によっ て選定され，その汎用性も検証されている值（表-1参 照）を使用し，SSTのM（以下，MS）は予測を行う上で RMSE，Dry-RMSEが総合的に小さくなるような值とし て, MS=2を選定した.

予測対象期間は，近年において比較的連続して観測が 行われている2004年〜2007年とし，NNMを適用する上 でのデータベース期間は1981年〜2003年とした.
表-1について，予測パターン(1)と予測パターン(5)の RMSEとDry-RMSEをそれぞれ比較すると特にDry-RMSE の值が良く低下し，予測精度が向上していることがわか る.これは, El Niño event発生時に水位低下が顕著にな るという既往の分析結果6) と乾季におけるSST と水位の 相関の高さから説明できると考える，さらに，予測パ ターン(2)〜(4)に着目寸ると, リードタイムが伸びるにつ れて予測精度が低下していく傾向にあることが読み取れ るが，一方で予測パターン(6)〜8に着目すると，2ヶ月 先予測〜4ケ月先予測においてはリードタイムに関わら ずRMSEとDry-RMSEが同水準で推移していることがわ かる．具体的に何ヶ月先まで予測精度を保ったままリー ドタイムを伸ばせるかについては更なる検証が必要では あるが，SSTを入れることによってリードタイムを伸ば した予測が可能であることが示されたといえる。なお， 今回の例では4ヶ月先予測までは精度を保ったまま予測 を行うことができ，5ケ月先予測から精度が低下してい く結果となった。 また, 実測水位と予測パターン(1)と予 測パターン(5)の比較を図-4に, 実測水位と予測パターン (7)の比較を図-5示す．ここで, 縦軸のASLは平均海水面 からの高さ (Above Sea Level) を表す. 図-4に着目する と，全体として精度が大幅に改善されている訳ではない が，予測パターン(1)では2005年に予測水位が振動してい る傾向であったのが改善され，さらに2007年の乾季の予 測の遅れも改善されていることが読み取れ，これが RMSE， Dry-RMSEの数值にも反映されていると考えら 


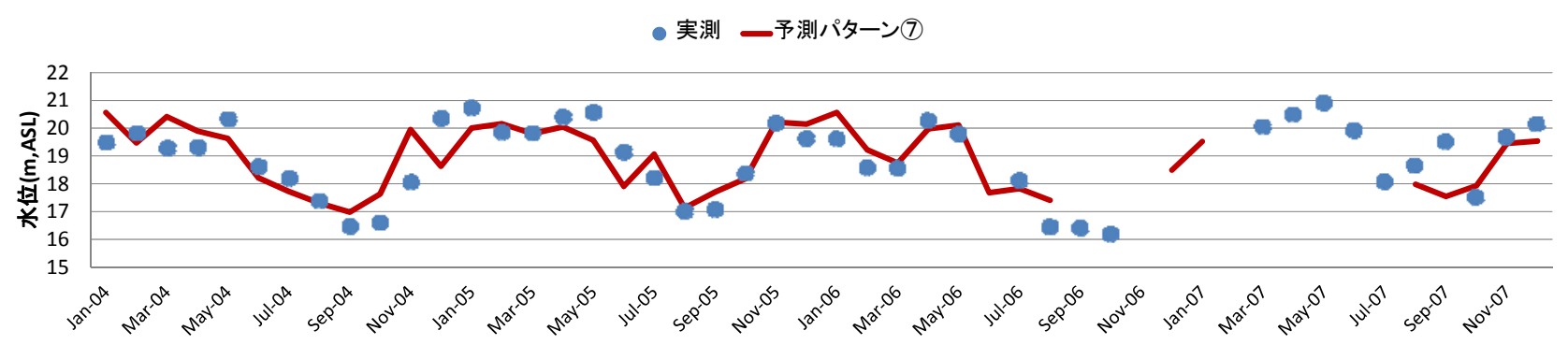

図-5 実測水位と予測パターン(7)の比較（リードタイム：3ヶ月）

れる。図-5に着目すると，予測精度が低下する期間も若 干見受けられるが，3ケ月といらリードタイムを考える と十分に評価できる.

\section{4. 流出モデルと予測雨量を用いた水位予測}

NNMは一種のパターンマッチング手法というその性 質上，図-4，図-5を見るとわかるように実測水位が欠測 となった場合その後の予測が行えないという問題がある が，これに対処するために本章ではNNMによって雨量 を予測し，予測された雨量を流出モデルに入力し水位予 測を行うことを試みる。また，そのためには流出モデル を構築する必要があるため, 最初に流域水収支の検証と 流出再現計算を行うことで流出モデルの検証と流域の基 礎情報の推定を試みた。 なお，水位予測の対象地点は前 章と同等にPalangkaRaya観測所，水収支の検証について もPalangkaRaya観測所流域を対象とする.

\section{（1）流域水収支の検証}

流出モデルによる流出再現計算を行いモデルの妥当性 を検証するためには水収支が担保された有効雨量を入力 することが必要である. よって本節では有効雨量と流出 高を比較してそのバランスを確認した上で水収支の定量 化を行い，有効雨量を推定するとともに流域の基礎情報 を得ることを目指した，なお，本研究における有効雨量 は流域平均雨量から実蒸発散量を差し引いたものを差す。 実蒸発散量の算出手順としては, 近藤(13)によるとイン ドネシア付近での実蒸発散量と可能蒸発散量の比は約 2/3であることからHamon法により可能蒸発散量を算出 した後，2/3を乗じて実蒸発散量とした。なお，可能蒸 発散量を算出するための気温データについては，流域直 近で長期的に気温を観測している地点がPalangkaRaya飛 行場（図-1参照）の1地点のみであることから，この気 温データを流域全体の気温として扱った。流域平均雨量 については，PalangkaRaya観測所とKualaKurun観測所の2 地点で観測された雨量の算術平均值を流域平均雨量とし た. ただし，流出計算を行うにあたっては日毎の連続し た雨量データが必要であるが，観測データには欠測があ る。そこで，PalangkaRaya観測所とKualaKurun観測所の じちらかが久測の場合は観測された1地点の雨量を，ど ちらも久測の場合はPalangkaRaya飛行場の観測雨量を流
域平均雨量とした。 なお，3地点の月平均雨量には相関 があることを確認している.さらに，本研究では全球降 水気候計画(Global Precipitation Climatology Project)（以下， GPCP) のプロダクトである0.5 グリッドデータ ${ }^{14)}$ (Full Data Reanalysis Version6)も合わせて使用することとし, 流域内に存在するグリッドを5点抽出（図-1参照）した 後，それらのデータを算術平均した流域平均雨量（以下， GPCP雨量）も用いた。 以上により算出した実蒸発散量 と流域平均雨量を用いて有効雨量を算出し推定した。

流出高については，Kahayan川では流量が定期的に観 測されていないことから辻ら ${ }^{5)}$ の手法と同様に，不定期 に観測された流量データより $\mathrm{H}-\mathrm{Q}$ 式を作成した後 PalangkaRaya観測所における連続水位データに適用し, 連続した流量データを推定し実測流量とした。 なお，使 用したH-Q式は， $H=0.13 Q^{0.5}-0.15+15.15$ (m,ASL)であり， 15.15はPalangkaRaya観測所の基準面からの水位をASLに 変換するための数值である.

検証期間については，長期的な検証を行うために PalangkaRaya観測所流域内において水位・雨量観測が始 まった1981年〜2010年とし, 有効雨量と流出高を年毎に まとめてその変動状況を示したものを図-6に示す。この 際，観測データの久測のために水収支の年単位量を算出 することが不可能であったため, 日平均值としてまとめ た.さらに，久測は存在するが長期にわたるデータを扱 うことによりおおよその年平均值を推定することができ ると考え，1981年～2010年の30年間のデータを用いて日 平均值を算出した後, 365を乗じることにより年平均值 を算出し，表-2に示した.

図-6に着目すると，実測雨量をもとにした有効雨量は 流出高と概ねバランスしており, 有効雨量の妥当性が確 認できた。また，GPCP雨量をもとにした有効雨量につ いて92年以前は流出高に対し比較的過小であるが，95年 以降は流出高とのバランスが改善され特に05年以降はか なり良くなっていることが見受けられる.このことは, 過去データから近年データにかけてのGPCP雨量データ の精度向上を表していると考えられ，今後は年間の水収 支などであれば全球降水量データであっても十分な精度 を保証した検証が行える可能性を示している，次に，表 -2の年平均の有効雨量と流出高の值に着目すると, 有効 雨量と流出高の間に300(mm/year)程度の誤差はあるもの の，Kahayan川では年平均でおおよそ2,300〜 2,700(mm/year)程度の流出があることが示され，流域の 


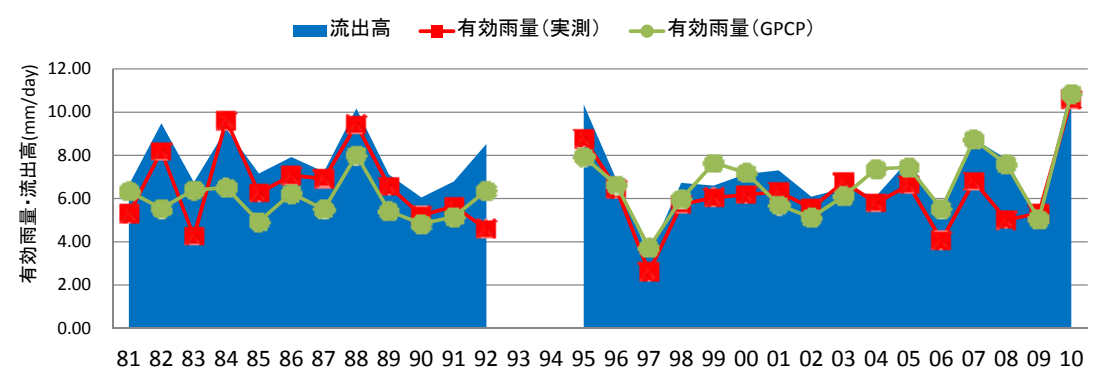

表-2 日平均と年平均の水収支

図-6 水収支の検証（93年は流出高の観測日数が0日，94年は2日のため欠測とした）

\begin{tabular}{|c|c|c|c|}
\hline & 81 年〜 10 年の平均 & $\begin{array}{c}\text { 日平均 } \\
\text { (mm/day) }\end{array}$ & $\begin{array}{c}\text { 年平均 } \\
(\mathrm{mm} / \text { year })\end{array}$ \\
\hline (1) & 実測降雨量 & 8.83 & 3223 \\
\hline (1) & GPCP降雨量 & 8.84 & 3226 \\
\hline (2) & 実蒸発散量 & 2.43 & 886 \\
\hline (3) & 有効雨量 (1)-(2)) & 6.40 & 2337 \\
\hline (3)' & 有効雨量 (1)'-(2)) & 6.41 & 2340 \\
\hline (4) & 流出高 & 7.28 & 2656 \\
\hline (5) & 誤差 (4)-(3)) & 0.87 & 319 \\
\hline (5)' & 誤差 (4)-(3)' ) & 0.87 & 316 \\
\hline
\end{tabular}

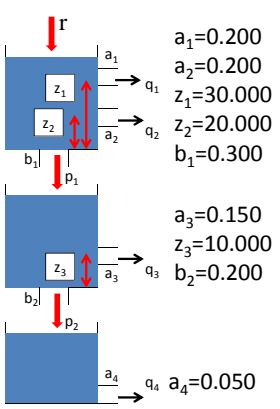

図-7 使用したパラメータ

水収支が明確化された.

\section{（2）流出再現計算}

PalangkaRaya観測所を対象地点とした流出再現計算を 行う。本研究では集中型3段タンクモデルを用い，計算 期間は1981年〜2010年として日単位での計算を行った. なお，各パラメータは辻ら5の検討をもとに若干の修正 を加えた值（mm-d単位）を選定した（図-7参照）。

計算結果を月単位にまとめ, 実測流量と計算流量を比 較したものを図-8に示す。なお，実測流量には久測があ るため, 前章の水位データの月平均值の算出と同様に月 平均流量データを算出した，図-8に着目すると，計算流 量は実測流量を概ね再現できていることがわかる。さら に，次節において水位予測を行う期間である2004年〜 2007年についてのNash効率係数は0.750であり，計算結 果の妥当性が確認できる.このことは前節においての流 域水収支の検証により有効雨量と流出高のバランスを検 証したことと, 各パラメータの選定が適切になされたこ とによる成果であると考える. 以上のことから, 流出モ デルの検証に加えてPalangkaRaya観測所における上流か らの水供給量の連続データの推定ができたといえる.

\section{（3）雨量予測}

NNMによる雨量予測を行う際も構成因子にSSTを組み 込むことを考える．構成因子を雨量のみとした場合と， 雨量とSSTを用いる場合の2パターン考え，それぞれに ついて予測計算（表-1，予測パターン9，予測パターン (10参照) を行った. なお， K, Mの值は実際に予測を行 う上でRMSE，Dry-RMSEが総合的に小さくなるような 值を選定した.

予測パターン (9) と予測パターン (10)のRMSE, DryRMSEのそれぞれの值を比較すると, SSTを構成因子に
実測流量 一計算流量

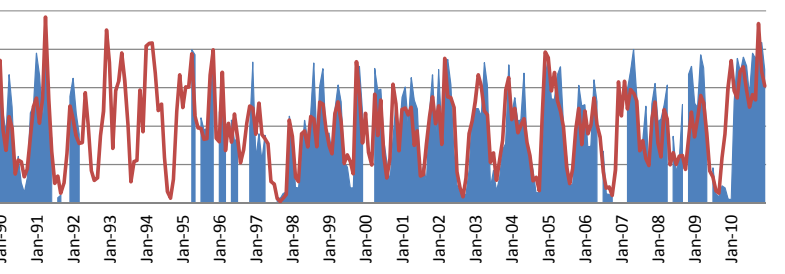

図-8 流出再現計算結果

入れることで予測精度が格段に向上することがわかり， Kahayan川流域における水文量の解析についてSSTを考 慮することの必要性が示されている. また, 実測雨量と 予測雨量の比較を図-9に示すが，予測雨量は実測雨量を 良好に再現できていることがわかる．水位予測を行う際 は，SSTを考慮した予測パターン10の予測雨量を用いる.

\section{（4）水位予測}

前節までで検証されたタンクモデルと得られた予測雨 量を用いた水位予測を試みる.この際，タンクモデルに よる計算を行うために月単位の值として与えられる予測 雨量を月の日数で除し, 日雨量データを作成して日単位 での計算を行う。次に出力された日流量をH-Q式を用い て日水位に換算し，月平均水位を算出し水位予測とした.

予測結果を表-1（予測パターン(11)），実測水位との比 較を図-9に示す。表-1を見ると，RMSE，Dry-RMSEの 值は予測パターン(5)に比べ劣っていることがわかる.こ れは，雨量予測を介した水位予測よりも水位そのものを 直接予測する方が良い精度を得られるためだと考える.

しかしながら, 図-9に着目すると, 水位の変動パターン を十分に捉えた予測を行うことができていると判断でき る. さらに，雨量予測を介した水位予測では，水位が久 測となった次の月であっても雨量が観測されていれば水 位予測を行うことができる.今回の事例では2004年〜 2007年の間に雨量の欠測がなかったため, 図-9を見ると 予測水位に欠測がないことが確認できる.すなわち，実 測水位が欠測であっても水位予測を行うことができる手 法を, 精度を確認した上で示すことができたといえる.

本研究では低水時の予測を重視していることを背景に 上記の手法の妥当性を考えると, 乾季の場合であれば降 雨量が少ないことから日単位降雨の変動の影響がさほど 大きくないと考えられる. よって，低水時予測を主眼と 


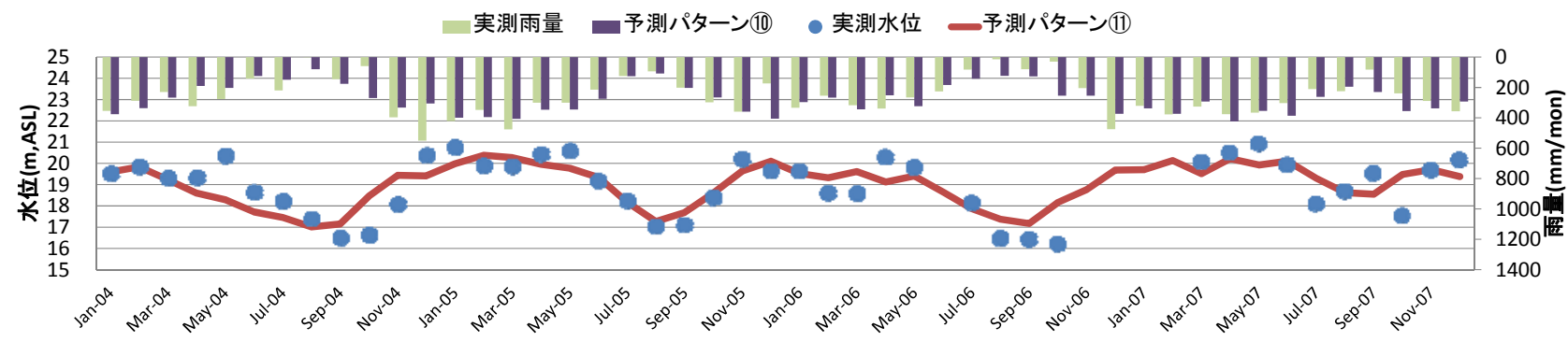

図-9 雨量予測結果と雨量予測を介した水位予測結果（リードタイム：1ヶ月）

した本研究においては十分な予測結果が得られると考え た，一方，雨季の場合は降雨量が多いために，予測精度 の一層の向上を目指すためには日単位の変動を考慮する ための手法をさらに工夫する必要があると考える.

また，実測水位のみならず実測雨量も欠測であった場 合の水位予測手法としてはGPCP雨量を用いることが考 えられる. GPCP雨量は任意地点で連続したデータを取 得できるデータセットであり，今回水収支の検証に用い ることでKahayan川流域における近年のデータの信頼性 が検証されたことから，GPCP雨量を用いた雨量予測に より水位予測を行うことが期待できる.

\section{5. まとめ}

本研究で得られた知見を下記に示す.

1) SST を NNM の構成因子に組み込むことで予測精度 の向上が見られ，さらにリードタイムを伸ばした予 測が行えることを示した.

2) 実測雨量データと GPCP 雨量データを用いて有効雨 量と流出高のバランスを確認した上で，水収支の定 量化を行うことができた.

3) PalangkaRaya 観測所でのタンクモデルによる流出計 算について再現性の良い結果が得られ，連続データ の推定ができた。

4) 雨量予測を介した水位予測を行い妥当な結果を得た ことで水位が久測であるときにも水位予測が行える ことが示された.

SSTをNNMに用いることで水位予測の精度を向上させ ることができ，さらにNNMを雨量予測に適用すること で水位データの久測に対応した予測手法を提案すること ができた．今後，河川水位とKalampangan運河の水位の 関係を分析することで，水位予測を泥炭地の乾燥化抑制 に役立てるための具体的手法の提案につなげていきたい.

謝辞 : 本研究は地球規模課題対応国際科学技術協力 (SATREPS)プロジェクトの「インドネシアの泥炭・森林 における火災と炭素管理」（代表 : 大崎満）の一部であ る. 本研究を遂行するにあたり Kahayan川関連データを 提供して頂き，また現地調査で大変お世話になりました CM-1(Carbon Management)班の高橋英紀氏，板倉忠興氏， 渡邊康玄氏, 山本浩一氏, 杉本光氏, Aswin Usup氏,
Adi Jaya氏，Untung Darung氏に対し，ここに記して深謝 致します.

\section{参考文献}

1) JST/JICA Project,パンフレット : Wild Fire and Carbon Management in Peat-Forest in Indonesia.

2) JST/JICA Project, HP: http://www.census.hokudai.ac.jp/html/JSTJICA/jp/index.html

3) 三宅龍平, 井上京, アディ・ジャヤ, ウントゥン・ダル ン: カリマンタン熱帯泥炭地における蒸発散量と流出量 の推定, 農業土木学会全国大会講演要旨集, pp.698-699, 2005.

4) Masayuki, K, Hidenori, T and Suwido, H. L. "Water Balance of a Peat Swamp Forest in the Upper Catchment of the Sebangau River, Central Kalimantan”, International Symposium on TROPICAL PEATLANDS, pp.299-306, 2000.

5) 辻弘平，中津川誠，工藤俊：インドネシア Kahayan 川流 域の水収支と流出量の推定について，土木学会北海道支 部論文報告集, 68 号, B-29, 2012.

6) 工藤俊, 中津川誠 : インドネシア Kahayan 川の水位変動 要因を踏まえた水位予測に関する研究, 土木学会水工学 論文集，第 56 巻， I -1471, 2012.

7) Karlsson, $\mathrm{M}$ and Yakowits, S. "Nearest-Neighbor Methods for Nonparametric Rainfall-Runoff Forecasting”, Water Resources Research Vol.23, No.7, pp.1300-1308, 1987.

8) Galeati, G. “A comparison of parametric and non-parametric methods for runoff forecasting”, Hydrological Sciences Journal, 35, pp.79-94, 1990.

9) 藤原洋一, 田中丸治哉, 畑武志, 多田明夫 : NearestNeighbor 法による多雪流域の実時間流量予測, 農業土木 学会論文集, No.210, pp.75-82, 2000.

10) 満倉真, 貞本均, 中津川誠 : Nearest-Neighbor 法による感 潮河川の水位予測, 水文・水資源学会誌, Vol.15, No.4, pp.371-380, 2002.

11) 三野基之, 中津川誠, 板倉忠興, 杉本光 : NearestNeighbor 法を用いたインドネシア Kahayan 川の水位予測, 土木学会北海道支部論文報告集，67 号，B-34, 2011.

12) 気象庁 HP: http://www.jma.go.jp/jma/index.html

13) 近藤純正 : 水環境の気象学, 朝倉書店, 1994.

14) ドイツ気象局 HP: http://www.dwd.de/

(2012. 9. 30受付) 